\title{
52. 安全性の高い流体圧力式釷子
}

\section{はじめに}

腸管切断時の理想的な吻合㓣治療のため, Albert-Lember ${ }^{11}$ 内維二層吻合, 最近注目され ている Gambee'2)の断端一層吻合, Jourdan ${ }^{3)}$ 法, 断端屓々吻合法など種々の吻合法の砛究がなさ 机ている。

また縫合材料としてよりよい材料Dexon" どの開発省って縫合不全による合併症の減少 に大きな寄寺がなされている。

しかしイレウス，その他炎症浮腫を伴う腸管 に対し使用寸る腸鎚子に上る圧迫障害注十分考 えられるが，この腸鉝子自体による組織障害を 最小に寸る安全性の高い理想的なものの検討や 砶究は泟と儿どなされていない。

\section{1. 目的}

われわ机は，腸管切断時の腸管に正える在迫 障害を改善寸るた可压縮性流体である空気压の 压迫力学利用した努全性の高い流体圧力式鉲子 の開発学行って扝り，合回はこの流体銊子がも つ血流遮断機能, 迕断解除後の血流回復過程扝 よび腸管組織に与える盾迫障害について調查検 討した。

\section{2. 方 法}

われわれが訊作した流体䣄子は，外径 $8 \mathrm{~mm}$ ， 肉厚 $0.1 \mathrm{~mm}$, 長さ $80 \mathrm{~mm}$ のシリコンチューブ の两端を塞ぎ空気压供給用のチューブを接続し

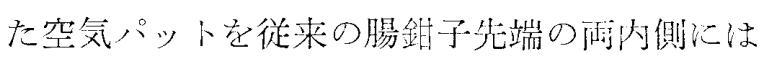
りつけ，この空気パットに空気压炎供繪仙来る

* 黒田精工

** 東宗大学医学部第 2 外科

\begin{abstract}
天羽輝彦* 江口省吾*山崎善弥** 高浜龍䖉**藤森義蔵水宫原透** 小西敏㿟** 山村卓也林片山惩恃** 和田達堆**
\end{abstract}

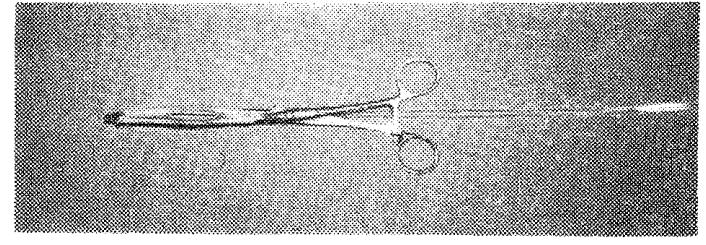

写真 1 試作した流体圧力式鉗子

ようにしたものである。写真 1 は試作した流体 圧力式鍵子である。

(1) 血流遮断機能の検討

ネンブタール㜂麻下の雑種成犬を開腹し，小 腸足腹腔外一露出し本流体錕子で挾儿だ後小腸 を切断する。この時の腸管断端面和らの流出血 流を肉眼的に確認しながら腸管を挾㐊压迫力す なわち空咗を変動させ，腸断端の血流が停 止, 再閒与る四方について検討した。 字た六腿 動脈を露出しそれに血汪測定用カテを雨入し, カラよりも中枢侧学本流体釷子で挾以只の時の 動脈圧と空気死を測定した。図1は2の実験図 である。

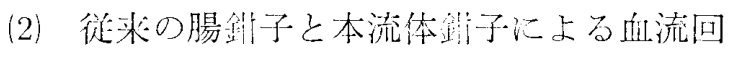
復過程の検討

(1)と同様にして，腹腔外一露出した小腸を従 来の腸錯子と本流体鋮子でまた参考の意㖠で血 管錯子及び止血鋪子で挾み15分放㗐した後, 各

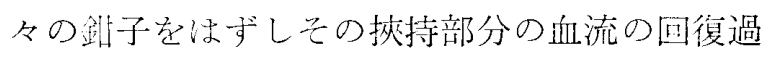
程をサーモグラフィ法により比較检討した。

(3) 腸管組織障害の検討

(2) と同様に，4種類の剑子で小腸を十分に挾 さみ15分放運後, 各々の挾持部学観察しかつ数 日後再開腹し，各々の鋪子で挾まれた部分の小 腸組織の圧迫障害について検討した。 


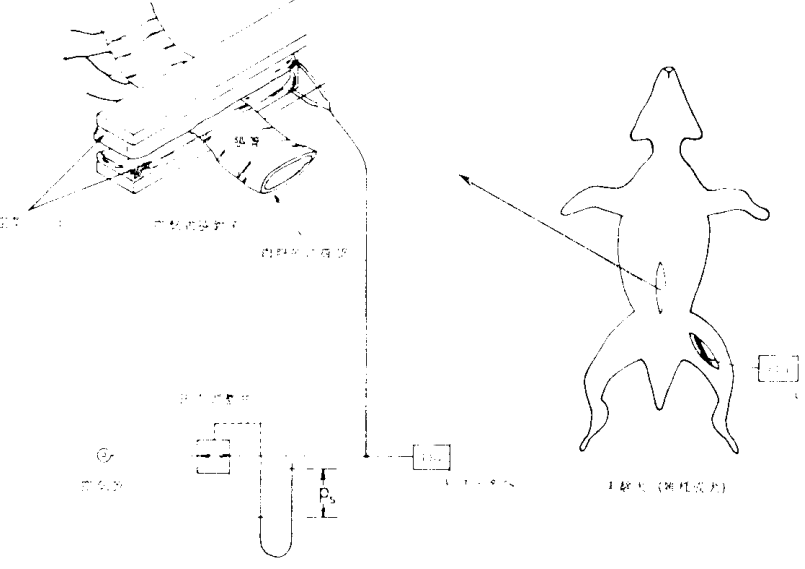

図1腸管断端血流停止圧力の測定

\section{3. 成 績}

(1) 血流造略機能について

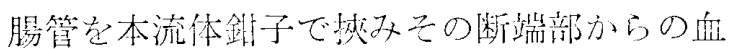

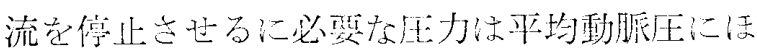

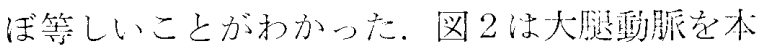

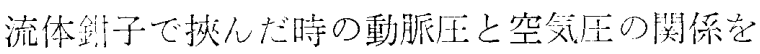

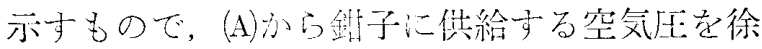

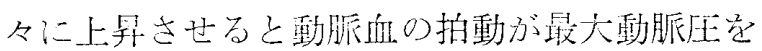

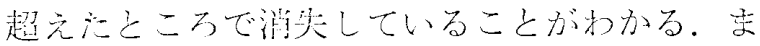

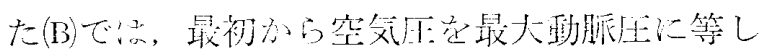
く調压し，三才去总介して断続的に空気压老倛

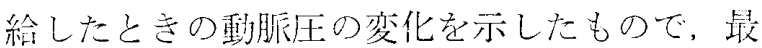

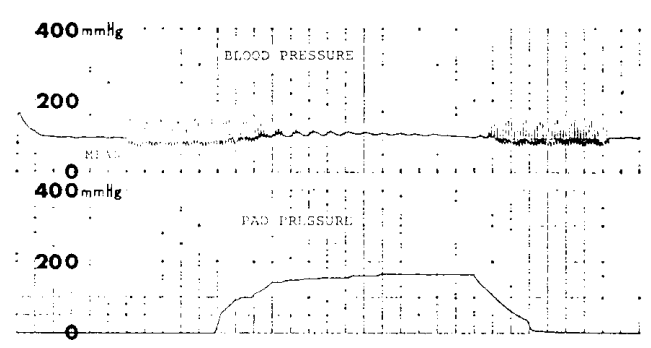

(a) パット内の压力を上昇させ血流停此圧力をみる

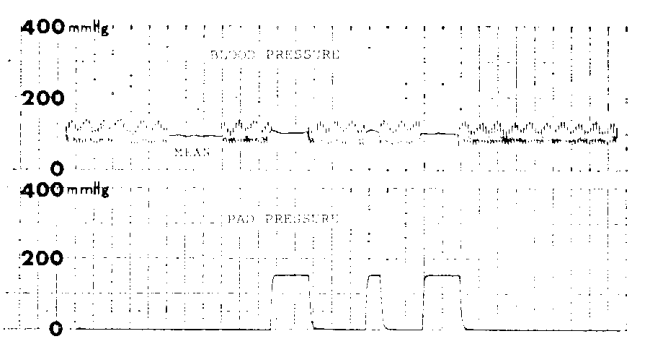

(b) パット内の压力を最大血圧に等しく調圧する

図 2 大腿動脈における動脈圧と空気パット 内圧力の関係
大動脈压に等しい空気在がかか机ばその 拍動が停止することがわかる。

(2) 血流回復過程について

写真 2 は 4 種類の鋪子で小腸を挾文子 15分放置後の血流の回復過程の変化老弉 間的にサー比アーで追跡したもの で，写真中の $\mathrm{A} \sim \mathrm{D}$ の示少黑く拔计た部 分が各々の䣄子で挾さまれた部分であ

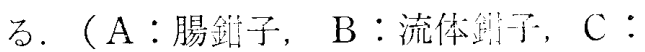
侮管料子， D：止血釷子）

これから24分経過後では，腸势子より 本流体鉬子の方が血流の国得受合（刍く なった部分）が大きいことがわわる。

(3) 腸管の組織障寒について

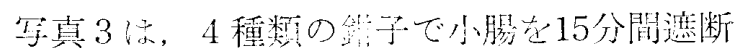

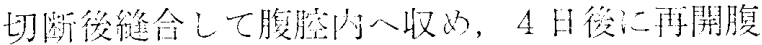
したと志のもので, 開腹所見沙次の通りである。

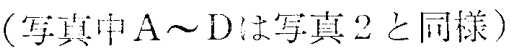

(o) 周䑶所胃

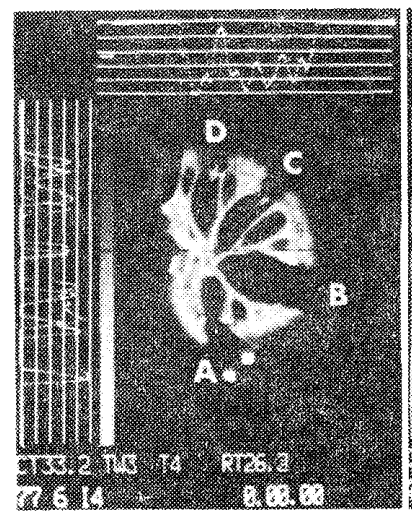

解除宣後

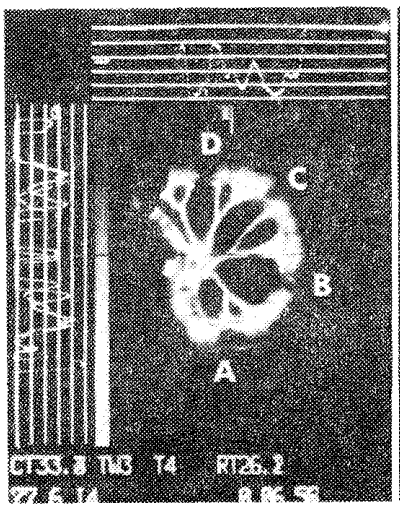

解除㣞 7 分

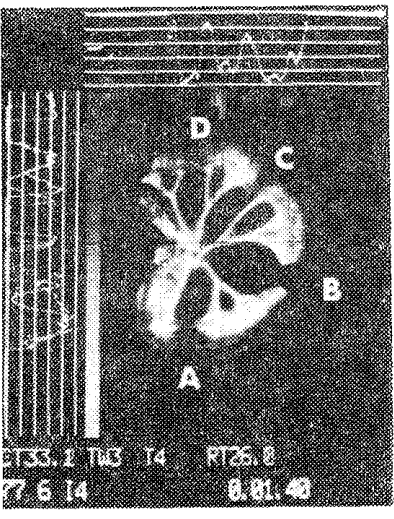

解除络 1 分 40 秒

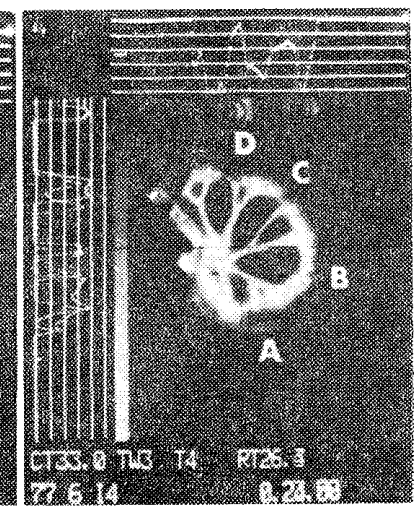

解除後24 分
写真 2 血流回復過程の時間的変化

(サーモグラフィ法による) 


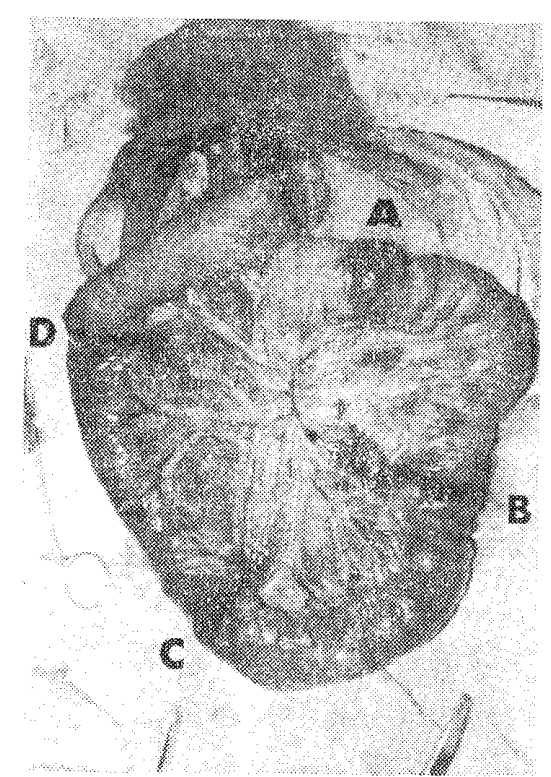

写真 3 踢合後 4 日経過後の各鋁子による 摤持部の状況

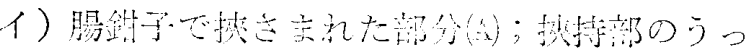

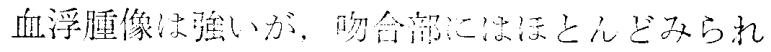
ない。

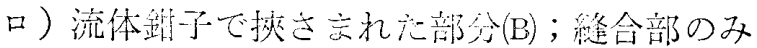

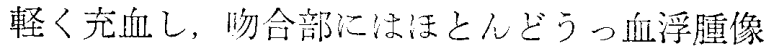
はみられない。

八）血管鉝子で挾さまれた部分(C)；吻合部周囲

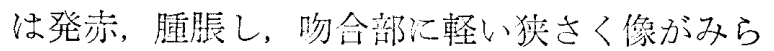
机た。

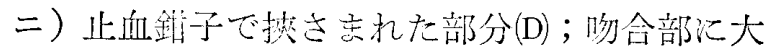
綱の付着があり，その周国は炎症反応が強くか

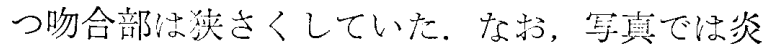

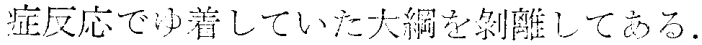

\section{4. 総 括}

血流遮断機能については，最大動脈圧に等し い空気圧汇等しい空気圧で十分であるが，腸管 組織への压迫障害を出来るだけ少なくするため 平均動脈压にまで下げることは可能であろう。 つぎに遮断解除後の血流回復過程については, 写真 2 からも明らかなよう飞流体此子の方が腸
鉗子と比心゙て血流国復範国が広くなっでりて

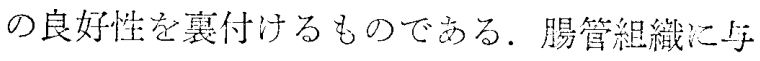

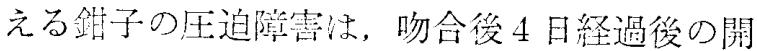
腹所見から腸跐子使用では吻合部周国心発赤, 浮腫, 睡脹などが認奶ら竌るのに対し，本流体 錐子使用ではこれらの変化が活と儿ど認められ ない，徒って鈿子の圧迫障害による組織障害と いう関点加ら本流体鎮子性往来の腸彭子よりも 優れていると考えられる。

\section{5. 績 論}

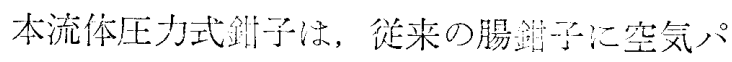

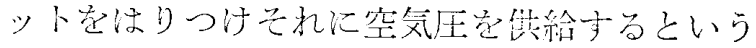

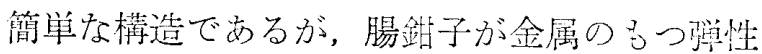
力を利用して圧泊寸るのと注異なり，空気圧の 马つ压縮性况利用するた暘管を一㥞な压力で 压迫できかつその压迫力も空気压を調整するこ とにより連続的かつ無段階汇摆節できるた内挾 持部の血流の回鿉も早く压迫障害も少ないもの といえる。今後法, 空気圧の発生部とこの圧力 調整部学出来るだけコンパクトにし，実際の使 用比酎えらるすの学試作・改良学雷祊ていく予 定で亦る。

\section{文 献}

1) Lembert, A:Merorie sur l'enteroraphie avec la Description dun Procede Nouveeau pour Pratiquer cette Operation Chirugicale. Report Gen. D' Anat. Phisiol. Path., $2: 100,1826$

2) Gambee, L. P. : A single-layer open intenstinal anastomosis applicable to the small as well as the large intentine. S. G. O., $59: 1,1951$

3) Jourdan, P.: A propos de la suture a plan uniqe destuniques disgestives. Acta. Chir. Belg., $54: 765,1955$

4) Craig, P. H. et al. : Surg. Gynecol. Obstet. $141: 1,1975$ 